\title{
RELIGIOUS NETWORKS IN MADURA Pesantren, Nahdlatul Ulama and Kiai as the Core of Santri Culture $^{1}$
}

\section{Yanwar Pribadi}

Laboratorium Bantenologi, State Institute for Islamic Studies (IAIN) Sultan

Maulana Hasanuddin, Banten, Indonesia

\section{Abstract}

This paper addresses three institutions in Madurese santri culture: the pesantren (Islamic traditional education system), the Nabdlatul Ulama, and the kiai (tradisional Islamic authority). These three elements have characterised and become central part of both Islam and politics in Madura. The issues are raised in this paper: the nature of pesantren, the role of Nahdlatul Ulama, and kiais within the whole tradition of santri Islam in Madura. How does each of these elements form relationships with the others? These questions lead to answer the main question: Is Islam in Madura different from Islam in other places in Indonesia? Today, it seems clear that despite their rather changed perceptions of modern education, Islamic associations, and men of religion, Madurese people continue to preserve their sacred values, as the main three elements of the santri culture in Madura which have had a great infuence on society, in both religious and worldly domains. The people share the view that Islamic law (shari'a) is fundamental to daily life and thus must be integrated in all aspects of life. However, like Islam in other places in Indonesia, the characteristic of Islam in Madura emphasises primarily, but not exclusively, on aspects such as mysticism and local cultures.

${ }^{1}$ This paper is part of Ph.D. dissertation at Leiden University. A number of data were collected from two sets of fieldwork from July 2009 until January 2010 and from October 2010 until July 2011 
[Artikel ini menjelaskan tiga elemen penting budaya santri yang melekat pada masyarakat Madura, yaitu pesantren, mewakili elemen pendidikan Islam tradisional, Nabdlatul Ulama, mewakili organisasi Islam, dan kiai, merepresentasikan tokoh Islam. Ketiga elemen tersebut berjalin-kelindan dan membentuk relasi yang kompleks antara Islam dan politik sebagaimana dipraktikean dalam masyarakat Madura. Dua persoalan penting yang hendak dijawab melalui artikel ini yaitu bagaimana karakter pesantren, Nabdlatul Ulama, dan kiai yang menjadi dasar Islam-santri di Madura dan bagaimana ketiga elemen tersebut saling terkait satu sama lain. Persoalan ini kemudian mengantarkan pada pertanyaan penting lainnya, yakni apakah Islam di Madura memiliki karakteristik dan bentuk yang berbeda dengan Islam yang hidup di wilayah lain di Indonesia? Sampai sekarang, meski masyarakat Madura mengalami pergeseran dalam menilai pendidikan modern, organisasi Islam, dan ulama, mereka masih tetap mempertahankan nilai-nilai sakral agama. Ini bisa dibuktikan dengan kuatnya pengaruh pesantren, Nabdlatul Ulama, dan kiai dalam urusan agama dan duniawi. Masyarakat Madura meyakini bahwa syariat Islam sangat penting dan perlu diterapkan dalam keseluruban aspek kehidupan mereka. Namun, seperti Islam di wilayah lain di Indonesia, Islam di Madura juga sangat dipengarubi oleb tasawnf dan budaya lokal.]

Keywords: Madura, Santri, Kiai, Pesantren

DOI: $10.14421 /$ ajis.2013.511.1-32

\section{A. Introduction}

Although Madura is not entirely different from other parts of Indonesia with regard to socio-religious characteristics, a stronger religious tradition appears to have emerged as a result of a long-term Islamisation process on the island, perhaps comparable to what we find Islam in Aceh and Banten. At least two forms of Islam can be identified in Madura: the santri culture and the non-santri culture. In the pesantren (Islamic tradisional boarding schools) tradition, we find santri ${ }^{2}$ (students

2 In the Indonesian languages, such as Javanese, Madurese, and Bahasa Indonesia (the official language of Indonesia), the term santri can be used in both singular and plural forms. Other non-English terms in this study can be used as both singular and 
of pesantren). However, in this study, referring to the term in pesantren tradition, santri is used primarily to refer to the majority of Madurese Muslims, proponents of more orthodox Islam with the global influences of Sunni Islam, the largest denomination school of the religion. In comparison, people of the non-santri culture are in the minority among Madurese Muslims. This last group also adheres Sunni Islam. They embrace less orthodox form of the religion influenced by local mystical belief systems. I would maintain that santri culture in Madura can be represented by three main elements: Islamic education institutions, Islamic groups and Islamic leaders. Like in other religiously-associated regions, such as Aceh ${ }^{3}$ and Banten ${ }^{4}$, traditions and customs of Madurese are rooted to religion. Consequently, it is not easy to draw clear distinction between tradition and religion.

This paper focuses on the aspects of santri Islam in Madura. It deals specifically with the principals on which three main elements of the Madurese santri culture- the pesantren that represents Islamic education institutions, the Nahdlatul Ulama (the NU) that represents Islamic majority, and the kiai (religious leader) that symbolises Islamic leaders-have characterised and have become central elements of both Islam and politics in Madura. Two major questions addressed in this paper related to the nature and character of the pesantren, the NU, and the kiai within the tradition of santri Islam in Madura, and how each of these elements forms relationships with the others. These questions lead to answer the main question: Is Islam in Madura different from Islam in other places in Indonesia?

Clearly, the kiai are the main actors in state-society relations in Madura. Along with other groups of local leaders, such as the blater (local strongmen) and the klebun (village heads), they are social, political, economic, and cultural brokers, a function which contributing in its own

plural forms as well.

3 Eric Eugene Morris, Islam and Politics in Aceh: a study of Center-Periphery Relations in Indonesia (Ithaca: Cornell University Press, 1983), p. 22; Yusny Saby, "Islam and Social Change: the Role of the Ulama in Acehnese Society," Ph.D. dissertation, Philadelphia: Temple University, 1995.

${ }^{4}$ Martin van Bruinessen, "Shari'a Court, Tarekat and Pesantren: Religious Institutions in the Banten Sultanate," Archipel, Vol. 50: Banten Histore d une Region, 1995, pp. 165-199. 
way the dynamic of society. It should be kept in mind that the general situation in Madurese villages is not free of conflict, not only between village officials and kiai, but also between individuals in the whole area. Villagers are divided into a number of loose groups with different orientations and interests. Utilising their capabilities and resources, village officials and kiai seem to have, openly or not, challenged each other in order to secure their own interests. The local government, via village officials, has attempted to reduce the political influence of kiai, especially during general elections. Meanwhile, through the networks of pesantren and the NU, the kiai have later responded to government's power by distancing themselves from the latter. This has created an odd situation, as the kiai are in fact needed by the government to ensure that politics goes smoothly at the grassroots level. As Elly Touwen-Bouwsma observes, at the village level, the support of the kiai is key to involving villagers in the implementation of government programmes. ${ }^{5}$

\section{B. Sketching Pesantren as the Core of Islamic Education in Madura}

In the history of Islam in Indonesia, pesantren is generally regarded as traditional Islamic educational institutions. Pesantren is traditional in terms of the content of education, which is primarily religious; in terms of teaching and learning processes; and of management, which is mainly in the hands of traditional ulama (religious leaders/teachers). There are at least three important roles of pesantren in Muslim community: the centre of transmission of religious knowledge; the guardian of Islamic tradition; and the centre of ulama reproduction. Pesantren, and similar institutions in other parts of Southeast Asia, such as surau, are the centres of rural religious life, and they tend to be tradition-oriented and socially conservative. ${ }^{6}$ Pesantren plays a crucial role in the santri culture since the

${ }^{5}$ Elly Touwen-Bouwsma, "The Ulama of Madura: Rise and Expansion of a Religious Regime," in Mart Bax, Peter Kloos and Adrianus Koster (eds.), Faith and Polity on Religion and Politics (Amsterdam: VU University Press, 1992), p. 100.

6 Azyumardi Azra and Dina Afrianty, "Pesantren and Madrasa: Modernization of Indonesian Muslim Society," Paper presented in Workshop on Madrasa, Modernity and Islamic Education, Boston University, CURA, May 6-7, 2005; Martin van Bruinessen, "Traditionalist and Islamist Pesantrens in Contemporary Indonesia," in Farish A. Noor, Yoginder Sikand and Martin van Bruinessen (eds.), The Madrasa in Asia: Political Activism and Transnational Linkages (Amsterdam: Amsterdam University Press, 2008), p. 218. 
nineteenth century of the Dutch East Indies. Despite their traditional characteristics, pesantren as the centre of education has developed into a central component of modernisation. ${ }^{7}$ Besides providing regular Islamic teachings, pesantren has offered general secular subjects as mandated by the government in state curricula, such as history, Western languages, and science. Thus, these institutions have endeavoured to modernise their santri using a distinctive method. ${ }^{8}$ In the contemporary period in Indonesia, the Ministry of Religious Affairs has reported that in the country there were 4,195 pesantrens with around 677,384 santris in 1977, in 1981 the numbers grew into 5,661 and 938,397 respectively. The number increased again in 1985, when the total number of pesantren and santri reached 6,239 and 1,084,801. This increasing trend was also evident in 1997, when the number, reached 9,338 and, 1,770,768 santris. In 2003-2004 the Ministry noted that there were 14,647 pesantrens. ${ }^{9}$ In the Indonesian archipelago, East Java province is the centre of the pesantren world. In Madura, Bangkalan and Pamekasan even label themselves "kota santri (santri town)," as other regencies in Madura, such as Sampang and Sumenep. ${ }^{10}$

In Bangkalan alone, based on statistical records, the number of pesantren in 2000 was 169, growing member from 145 in 1995. The number of male santri in 2000 was 21,131 and female santri was 20,013.

7 Along with pesantren, the Sarekat Islam (the SI) in the early twentieth century introduced Madurese to the modern world. The SI provided Madurese with a new alternative in vertical relations between villagers and those who resided in town areas. A new alliance between urban intellectuals and rural religious leaders marked a new phase in the history of Indonesian politics. See Kuntowijoyo, "Islam and Politics: the Local Sarekat Islam Movements in Madura, 1913-20," in Taufik Abdullah and Sharon Siddique (eds.), Islam and Society in Southeast Asia (Singapore: Institute of Southeast Asian Studies, 1988), p. 109.

8 Ronald Lukens-Bull, "Teaching Morality: Javanese Islamic Education in a Globalizing Era," Journal of Arabic and Islamic Studies, Vol. 3, 2000, pp. 26-48.

9 Departemen Agama RI, Data Potensi Pondok Pesantren Selurub Indonesia Tabun 1997 (Jakarta: Departemen Agama RI, 1997); Departemen Agama RI, Daftar Pondok Pesantren Selurub Indonesia, 2003- 2004 (Jakarta: Departemen Agama RI, 2004) quoted in Jajat Burhanudin, "Islamic Knowledge, Authority and Political Power: the Ulama in Colonial Indonesia," Ph.D. dissertation, Leiden: Leiden University, 2007, p. 2.

${ }^{10}$ Nowadays such claims are rather common in Java. Pandeglang in the Banten province has called itself a santri town, while in the provinces of West Java and East Java, the regencies of Tasikmalaya and Jombang have the same claim. 
In 1995 , the number of male santri was 13,711, while the number of female santri was 12,314. In 2000, the number of pesantren custodians, that is the main kiai and other guru ngaji (teachers of Islamic knowledge and Quran reciting), was 2,323 males and 258 females (note that in 1995 the member of kiais were 734 males and 455 females). ${ }^{11}$ In 2006, the number of pesantren in Bangkalan was 305 with 34,013 male santri and 30,013 female santri. The number of male kiai pesantren was 2,427, while there were 1,283 female kiai. ${ }^{12}$

In Sampang, the number of pesantren in 2000 was 106. The number of male santri in the same year was 17,612, while female santri 11,934. There were 1,055 male and 426 female pesantren custodians..$^{13}$ The number of pesantren in Sampang in 2009 grew to 282, whereas the male santri in the same year reached 33,650 and the number of female santriwas 22,745 . The number of custodians in 2009 was 3,907 of males and 316 of females. ${ }^{14}$

Despite the introduction of secular public and private schools in the villages in Madura in recent years, the number of pesantren has grown. One of the most important factors in the survival of pesantren in the history of Islam in Indonesia is their ability to accommodate the rapidly changing situation without losing some of their fundamental traditional characteristic. ${ }^{15}$ This is to some extent unsurprising, given the historical fact that religious education has played a significant role in the history of education in Indonesia. For example, pesantrens were the only form of education in Java prior to the twentieth century. ${ }^{16}$ In nineteenth-century Madura, religious education fulfilled the need for Islamic knowledge, which was also seen as general knowledge. There were hardly any mosques in nineteenth-century West Madura, only one in Bangkalan and one in Sampang. ${ }^{17}$ However, langgar (small mosques)

11 BPS, Bangkalan dalam Angka 2000, p. 83.

12 BPS, Bangkalan dalam Angka 2007, p. 146.

13 BPS, Sampang dalam Angka 2000, p. 48.

14 BPS, Sampang dalam Angka 2010, p. 97.

15 Azra and Afrianty, "Pesantren and Madrasa", p. 2.

16 Taufik Abdullah, "The Pesantren in Historical Perspective," in Taufik Abdullah and Sharon Siddique (eds.), Islam and Society in Southeast Asia (Singapore: Institute of Southeast Asian Studies, 1988).

17 Touwen-Bouwsma, "The Ulama of Madura", p. 111. Mosques usually had penghulu (state religious officials) attached to them. At the end of the eighteenth century in Nusantara (Indonesia before independence), penghulu at the regency level 
were abundant. Langgar, besides functioning as houses of prayer, also served as the lowest level education institutions and led by local religious teachers. In 1893, there were more than 50,000 langgars in Madura where children were introduced to basic Quran recitation, as the next step was entry into a pesantren if they wished to advance their knowledge. ${ }^{18}$

Pesantren in Madura are similar to those in Java and the Malay Peninsula. These institutions are centres of the transmission of traditional Islam with kitab kuning (the yellow books) serving as classical texts of many branches of Islamic knowledge ${ }^{19}$ These Islamic education institutions did not emerge before the eighteenth century, and in fact, they only became widespread in the latter half of the nineteenth century in the Netherland East Indies. ${ }^{20}$

Pesantren exclusively belonged to kiai or a kiai family, and were seen as religious centres for the education of santri who wished to become religious leaders. Pondok (lodges) as part of pesantren were built in order to facilitate santri who came from afar to reside in the pesantren. In Pamekasan, according to oral tradition, Pesantren Batuampar was established around

were appointed by the VOC as court advisors. In West Sumatra a penghulu was a head of the nagari (similar to Javanese villages), whereas in Riau the position was at the same level as a village head. In Java and in Madura penghulu were religious officials in Islamic kingdoms and in regencies under Dutch rule. They had full authority in all state affairs concerning Islamic matters, mostly in the implementation of shari'a law (Islamic law). They also served as the heads of mosques, their main duties being to lead prayers and educate the umma (Muslim community). Penghulu had higher authority than qadi (judges) or mufti (one who issues fatwa - non-binding opinions concerning Islamic law) in classical Islamic countries because of their roles in religious education in addition to their roles as heads of mosques. See Muhammad Hisyam, "Potret Penghulu dalam Naskah: Sebuah Pengalaman Penelitian," Wacana, Vol. 7, No. 2, 2005, pp. 125-133. In West Madura in the nineteenth century, penghulu were appointed and paid by the West Madurese rulers like most of the officials. See Touwen-Bouwsma, "The Ulama of Madura”, p. 111.

${ }^{18}$ Kuntowijoyo, "Agama Islam dan Politik: Gerakan-gerakan Sarekat Islam Lokal di Madura, 1913-1920," in Huub de Jonge, Agama, Kebudayaan, dan Ekonomi: Studi-studi Interdisipliner tentang Masyarakat Madura (Jakarta: Rajawali Pers, 1989), p. 43.

19 Martin van Bruinessen, "Pesantren and Kitab Kuning: Continuity and Change in a Tradition of Religious Learning," in Wolfgang Marschall, Texts from the Islands: Oral and Written Traditions of Indonesia and the Malay World (Bern: Institute of Ethnology, University of Bern, 1994), p. 121.

${ }^{20}$ Ibid., p. 131-133; Martin van Bruinessen, "Shari'a Court, Tarekat and Pesantren", pp. 173-176; Merle Calvin Ricklefs, Polarising Javanese Society: Islamic and Other Visions, c. 1830-1930 (Leiden: KITLV Press, 2007), pp. 52-72. 
the second half of the nineteenth century. In Bangkalan, Pesantren Syaichona Kholil Demangan of the famous Kiai Kholil, is also said to be founded at the same time. In the nineteenth century, there were statistical reports about the number of santri in Madura. For instance, in 1865 there were 2,504, in 1866 9,674, and in 1871 18,106. ${ }^{21}$

Children of the Madurese elite had more options in schooling when the Dutch administration introduced secular education among the ruling aristocracy in the late nineteenth century. Even though the establishment of secular schools affected the number of pesantren pupils, religious learning was still well-suited to the prevailing expectations among the priyayi (local aristocracies) who wished their heirs to master wide-ranging knowledge of both worldly and religious concepts. ${ }^{22}$ To cope with the popularity of the religious schools, in 1905 the Dutch government issued a regulation to register all pupils and teachers at religious school, as well as teachers of ngaji (Quranic recital), kitab (religious books) and tarekat (Muslim mystical brotherhoods). ${ }^{23}$ It was apparently common for santri to undertake lessons in different pesantrens. Studying in pesantren in Java became the next phase for highly motivated santri who, subsequently, would go to Mecca with financial support of their family.

Many modern pesantren in Madura have attempted to combine secular subjects and Islamic teaching. According to Lukens-Bull, mixing the two is a way in which kiai and other pesantren figures (who together make up the pesantren custodians) are arranging 'Islamic modernity. ${ }^{24}$

${ }^{21}$ Kuntowijoyo, Perubahan Sosial dalam Masyarakat Agraris Madura, 1850-1940 (Yogyakarta: Matabangsa, 2002), p. 331.

22 One example is Pangeran Aria Achmad Djajadiningrat, who spent some time in pesantren in the $1880 \mathrm{~s}$, before the Banten revolt in 1888. He went on to continue his studies at the Willem III School in Batavia. See Burhanudin, "Islamic Knowledge", pp. 121-122. Meanwhile, several members of the kraton (palace) of Yogyakarta were also educated in pesantren. See John Pemberton, On the Subject of "Tava" (Ithaca: Cornell University Press, 1994), pp. 48-9.

${ }^{23}$ Kuntowijoyo, "Agama Islam dan Politik", p. 46.

${ }^{24}$ Lukens-Bull, "Teaching Morality", pp. 34, 38, 42. In his study of three pesantren in East Java, Lukens-Bull suggests that kiai play arole in redefining modernity. Modernity in the pesantren world is seen as a set of normative values that must be compatible with Islamic norms. Therefore Western materialism does not suit the criteria of Islamic modernity. For pesantren people, modernity is the combination of religious learning, development of character, and secular schooling. These variables are designed to make Muslims capable of living in a world without losing their Islamic values. 
Like in Java, pesantren in Madura emphasises Islamic teachings in their curricula, including, among others, Arabic learning, canonical collections of traditions (hadith), Quran recitation and Quranic exegeses (tafsir). Some offer Madurese mystical Islam exercises. Others offer Quranic memorising ${ }^{25}$ or martial arts lessons. ${ }^{26}$ Although many pesantren in Madura now run their education systems in a more modern manner, in keeping with their more traditional counterparts, strict obedience to the kiai remains a distinct tradition that is maintained in every pesantren.

During the New Order period, most pesantren leaders have developed a more dynamic mindset in response to the challenges posed by Soeharto's administration to fulfil the rising demands of employment in the business and government sectors following the development plans established by the new administration. The modernisation process is evident in the participation of some pesantren people in politics. The involvement of kiai pesantren (kiai who lead pesantren) in politics during the New Order, however, does not indicate a change in stance among traditionally conservative kiai into reformed and progressive ones. Although there is a tendency for kiai to give their political support to Partai Persatuan Pembangunan (PPP - the United Development Party), most Madurese kiai kept their distance from political parties during the New Order. Only a few kiai openly participated in politics. The new patterns of kiai in politics, such as guiding older santri to support certain political party, were only evident in few pesantrens.

In Bangkalan, the celebrated Pesantren Demangan, and its associated pesantren, ${ }^{27}$ and Pesantren As Shomadiyah were places that

25 Such as Pesantren Bustanul Ufat Assyaiin in Sampang.

${ }^{26}$ Such as Pesantren Nuril Islam Gili in Kamal sub-district of Bangkalan, established in 2000 by Kiai A. Bazids. Initially, it was a perguruan beladiri and tenaga dalam (martial arts and inner power college). Kiai Bazids is not of kiai descent, yet he was traditionally trained in pesantren. In his youth, he often went in search of esoteric sciences. Unlike many contemporary pesantren which offer formal education recognized by the government, this pesantren does not offer such a formal education. At Nuril Islam Gili, the santri may have formal education outside the pesantren. Nuril Islam Gili applies takerir (memorising) and tahfizal-qur'an (reciting and memorising the Quran) methods in its tutoring system. Both are conducted every evening, except Thursday evening when martial arts lessons and inner power practices are taught.

27 There are a number of pesantren that have close connections, or claim to have interrelated ties with Pesantren Demangan. These connections are not exclusively based 
affirmed people's political aspirations during Suharto's era. In Sampang, Pesantren At Taroqqi of Kiai Alawy Muhammad served a similar function. So long as the kiai of these pesantrens remained as functionaries or at least supporters of the PPP and championed the party, their constituents would vote the PPP. A number of kiais, whom I talked to, emphasised the vital position of the Kiai Kholil family. During the New Order, the entire Kiai Kholil family, such as Kiai Amin Imron, Kiai Makmun Imron and Kiai Abdullah Schal, ${ }^{28}$ openly supported the PPP.

In other regencies, Sumenep for instance, not all areas are strongly influenced by orthodox Islam or santri culture. Places in Sumenep, such as Saronggi, Kalianget, and Gapurana, have preserved the tayu ${ }^{29}$ tradition up to the present. ${ }^{30}$ Nevertheless, Sumenep is still highly regarded as a centre of religious schooling, for there are many respectable pesantrens, such as in Guluk-guluk and Prenduan. Moreover, among the modern pesantren in

on family bonds. To name a few, Pesantren Syaichona Kholil 2, Pesantren Ibnu Kholil, and Pesantren Al Muntaha Al Cholili.

${ }^{28}$ Schal is an abbreviation of Syaichona Kholil. Syaichona is an honoured title for Kiai Kholil. The title was attributed to Kiai Abdullah Schal when he became central figures of the PPP, not only in Bangkalan, but also at the national level.

29 Tayub or tayuban is a traditional Central and East Java performing art whose dancers are called tledhek, taledhek, ledhek, tandhak or tandak. It is not only a recognised form of entertainment, but also an integral part of spirit shrine ritual associated with the annual bersib desa (spirit shrine ritual) festivity. In Yogyakarta the word tayuban is said to derive from the words mataya, meaning 'dance' in the Kawi language, and guyub, which means 'communality or harmoniousness'. See Robert W. Hefner, "Islamizing Java? Religion and Politics in Rural East Java," The Journal of Asian Studies, Vol. 46, No. 3, 1987, pp. 533-54; Felicia Hughes-Freeland, "Tayuban: Culture on the Edge," Indonesia Circle, No. 52, 1990, p. 39. The tledhek themselves claim to be Muslim, with some insisting that they are good Muslims. See Hefner, "Islamizing Java?", pp. 533-554. Tayuban is also related to the traditional Javanese wedding ceremony, being performed after the ceremonial meeting of the bride and groom. This tradition is believed to have started in pre-Islamic times. See Clara Brakel-Papenhuyzen, "Javanese Taledhek and Chinese Tayuban," Bijdragen tot de Taal-, Land- en Volkenkunde, Vol. 151, No. 4, 1995, p. 546. Tayub in Madura is associated with that in Tengger, Pasuruan. In Gapurana, however, tayub performance is not necessarily identified with the bersib desa activity like in Tengger. It is held mostly during wedding feasts in which offerings to supernatural spirits play an integral part. See Muhammad Endy Saputro, Kiai Langgar and Kalebun: A Study on Contestation between Cultural Brokers in a non-Pesantren Village in Madura, Indonesia (Yogyakarta, Graduate School Gadjah Mada University, 2009), pp. 54-5.

${ }^{30}$ Ibid., p. 54. 
Madura, Pesantren Al-Amien in Prenduan, Sumenep, is worthy of note, as it is particularly famous for its Arabic-oriented orthodoxy. With regard to this pesantren and the kiai in this religious network, it is worth noting how different the development of Islam has been. In Sumenep the areas of Prenduan and possibly Guluk-guluk may be considered more orthodox in terms of religious orientation than the rest of Madura. Syarqawi, the founder of the Pesantren Al-Amien was a learned man whose ancestors came from Kudus, Central Java. However, his leadership of the pesantren was short-lived, because the more traditionally religious-oriented people in the area rejected his strong Arabic orthodoxy and suspected the fact that he came from outside Madura. Following his expulsion, he established a pesantren in Guluk-guluk. His old pesantren in Prenduan was passed down to his disciple, Kiai Achmad Chotib. ${ }^{31}$ The expulsion of Syarqawi from Prenduan by local people is similar to the situation of the Muhammadiyah (the second largest Islamic organisation in Indonesia) since its introduction on the island. The traditional features of Islam in Madura indicate that many modernist Islamic ideas, like Muhammadiyah's attempts to 'purify' un-lawful innovation of Islamic traditions (bid'ab), is not well accepted.

\section{Outlining the Nahdlatul Ulama as the 'Religion' of the Madurese}

The NU has a great impact on Madura. For instance, in the 1971 general elections (Pemilihan Umum/Pemilu), of the total number of votes in all regencies in Madura, 817,561 went to the NU party and 300,399 to Golkar, compared, for instance, in East Java province only $4,379,806$ went to the NU and 6,837,384 to Golkar. ${ }^{32}$ At glance, these numbers show us how central the NU and PPP were in 1971 to the Madurese in general and to the Madurese kiai in particular, since the kiai were the most important factor behind the success of the party in persuading the people in politics.

The NU is by far the largest Islamic organisation in Indonesia, with approximately forty to fifty million followers who are heavily concentrated

${ }^{31}$ Huub de Jonge, Madura dalam Empat Zaman: Pedagang, Perkembangan Ekonomi, dan Islam: Suatu Studi Antropologi Ekonomi (Jakarta: Gramedia, 1989), pp. 242-4.

32 BPS, Pemilu 1971 di Jawa Timur, pp. 170-1. 
in Central and East Java provinces. ${ }^{33}$ The organisation was founded on 31 January 1926 in Surabaya by a number of renowned kiai, most of whom owned Islamic boarding schools, including Kiai Hasyim Asy`ari of Jombang and Kiai Wahab Hasbullah of Surabaya. The NU sees its function as being the guardian of sacred tradition by maintaining the four madhab teachings, although it is the Shafi'i religious school that has been predominantly embraced by Indonesian Muslims. ${ }^{34}$ This indicates the NU's acknowledgement of the great ulama of the four madhab in interpreting the Quran and hadith. From its inception, the NU's main base of support has been rural East Java, including Madura where traditional Javanese practices and ways of life absorbed elements of Islam. Rural kiai have authority especially when their influence is bolstered by a web of martial alliances between leading kiai families and a network of kiaisantri relationships throughout East Java. This social base of support for the NU has expanded over time, also attracting some urban and more educated followers. ${ }^{35}$

In the later period after the establishment of the NU in 1926, the decline of the SI in Madura marked a new era in Madurese history. The association of the SI with modern and reformed attitudes was unsuccessful in drawing Madurese people to get involved in politics. Following the decline of the SI, the NU plays a central role with the most rural followers who actively participated in politics. People are attracted to the NU primarily because of the non-political orientation of the organisation during its early years, whereas the political orientations

33 See Mitsuo Nakamura, The Crescent Arises over the Banyan Tree: a Study of the Muhammadiyah Movement in a Central Javanese Town (Yogyakarta: Gadjah Mada University Press, 1983); Andrée Feillard, NU vis-à-vis Negara: Pencarian Isi, Bentuk dan Makna (Yogyakarta: LKiS, 1999); Saiful Mujani and R. William Liddle, "Indonesia's Approaching Elections: Politics, Islam, and Public Opinion," Journal of Democracy, Vol. 15, No. 1, 2004, p. 111.

${ }^{34}$ Bernard Johan Boland, The Struggle of Islam in Modern Indonesia (The Hague: Nijhoff, 1982), p. 11; Feillard, NU vis-à-vis Negara, p. 13.

35 Allan A. Samson, "Conceptions of Politics, Power, and Ideology in Contemporary Indonesian Islam," in Karl D. Jackson and Lucian W. Pye (eds.), Political Power and Communications in Indonesia (Berkeley: University of California Press, 1978), pp. 196-226. 
of the SI led to losing followers. ${ }^{36}$ As in Java, in Madura most nabdliyin (coined to mention the followers of NU) perceived the NU primarily as a religious organisation, rather than a political association. The NU has become popular and taken over the SI's position in the late 1920s, as an organisation that was able to spread out to rural areas.

The NU attracts local kiai and many villagers, due to its perspective that appreciates more traditional and syncretist aspects of Islam in Madura. In addition, the prominence of Kiai Kholil of Bangkalan was also used by NU leaders to encourage a sense of pride among Madurese religious leaders by stressing that Kiai Hasyim Ashari, Kiai Wahab Chasbullah, Kiai Bisri Syansuri, and Kiai Maksum, all founding members, were once students of Kiai Kholil. NU leaders expected, therefore, that Madurese ulama would be proud of their legendary Kiai. Being members of the NU, or even just being sympathetic to the NU, was interpreted as protecting Islam from potential threats of reformists and modernists. The success of the NU's top figures in rallying their colleagues was a reflection of rural Muslim life in the Archipelago centering in pesantren. The NU was also far more hospitable than the SI or the Muhammadiyah to mystical-magical practices and the NU kept strictly to the old traditions, showing a lack of interest in shifting direction towards a more modern stance. The NU's conception of Islam seems to have fit the Madurese santri culture.

Under Suharto's authoritarian administration, Indonesia experienced the enforced adoption of Pancasila (the official five pillars and philosophical foundation of the Indonesian state) as the sole ideology. Suharto's administration used Pancasila to curtail religious freedom, forcing Indonesians to accept it in a standardised way. There was almost no opportunity to disagree with, or to oppose the state's version of Pancasila. ${ }^{37}$ All Muslim associations, either in the form of political parties or socio-cultural movements, were forced to accept Pancasila as their sole philosophical base. The NU accepted the idea to varying degrees. Within the association, kiai and politicians competed with each other for ultimate leadership of the NU. This struggle was prominent after the

${ }^{36}$ Martin van Bruinessen, NU, Tradisi, Relasi-relasi Kuasa, Pencarian Wacana Baru (Yogyakarta: LKiS, 1994), pp. 47-8.

${ }^{37}$ Nicola Colbran, "Realities and Challenges in Realising Freedom of Religion or Belief in Indonesia," The International Journal of Human Rights, Vol. 14, No. 5, 2010, p. 682. 
1982 general elections (i.e. in the immediate aftermath), when a group of Madurese kiai demanded that the NU avoid politics by leaving the PPP. Despite its acceptance of Pancasila, a number of Madurese kiai in the NU refused to officially adopt Pancasila as the ideological base of the organisation. ${ }^{38}$ Even today, many of the kiais in Madura, with whom I had conversations, are still not in favour of Pancasila, and consider the philosophical ideology as a legacy of secular government.

For many santris in Madura, being a Muslim means being a sympathiser of the NU. This strong identification with the NU does not automatically mean that they have to officially become a member of the organisation. They are considered to be born as true nabdliyin who will guard the principles of Sunni Islam and obey instructions of kiais. In Madurese politics, this means that not voting for the NU party, or NU-associated political parties, is sinful ${ }^{39}$ During the New Order, it was even worse if political muslim support Golkar, a government party that was seen as the major threat to Islam. ${ }^{40}$ Nonetheless, although there was a political barrier between the leaders of NU and the government, NU elites in Madura were aware that recognition from the state was crucial in promoting their organisation in villages. For instance, prior to the 1984 Situbondo Muktamar (NU National Congress), leading figures of NU Pamekasan repeatedly emphasised the government's agreement, which included the President's permission to hold the 1984 congress. $^{41}$

Before the 1971 elections, the NU in Madura had openly sponsored

38 Iik Mansurnoor, Islam in an Indonesian World: Ulama of Madura (Yogyakarta: Gadjah Mada University Press, 1990), p. 379.

39 After 1973 the support turned to the PPP, and in the post-Suharto period the majority support was given to the PKB with some to the PKNU. Prior to the 1971 elections, Kiai Bisri Syansuri issued a fatwa stating that it was an obligation for Muslims to participate in general elections and to vote for the NU. See Martin van Bruinessen, NU, Tradisi, Relasi-relasi Kuasa, p. 98. He issued another fatwa before the 1977 elections, this time asking Muslims to vote for the PPP.

${ }^{40}$ Other areas showed a similar attitude. For instance, in Jombang, Kiai Musta'in Romly (d. 1985) of Pesantren Darul Ulum, Rejoso, was of Madura origin and never occupied a vital position within the NU. His choice to represent Golkar in the DPR (the National Parliament) led to discrimination by his colleagues. See Martin van Bruinessen, "Tarekat and Tarekat Teachers in Madurese Society," in Kees van Dijk, Huub de Jonge and Elly Touwen-Bouwsma (eds.), Across Madura Strait: the Dynamics of an Insular Society (Leiden: KITLV Press, 1995), p. 99.

${ }^{41}$ Mansurnoor, Islam in an Indonesian World, pp. 123-4. 
many village festivities. Following the participation of Golkar in the 1971 elections, efforts to transform village officials into Golkar cadres and sympathisers became trend. This led to the reluctance of the village officials to support the NU. Consequently, many village festivities were held neutrally under local initiatives. Furthermore, during the New Order, despite its departure from politics, the NU continuously attempted to maintain its dominance in the PPP. As a result, the government could not neglect NU activities in villages. Under Suharto's administration, this uneasy relationship manifested itself in the government's limitation to NU social activities. One of consequences was preventing the NU from posting signs in front of any NU offices or its leader's home in the villages. ${ }^{42}$ Today, it is common to see NU signs in many places in Madura, such as in every fifty to one hundred metres along the main road in Bangkalan, which connects the regency with Sampang. Moreover, it is now beneficial to have a strong identification with the NU, especially for new and young cadres who are just involved in politics, as the NUdespite its 'repression' by the New Order administration-has always been a favourable political vehicle capable of placing its cadres in important political posts.

The withdrawal of the NU from the PPP after the 1982 elections led to bewilderment in the local context. ${ }^{43}$ While in other places the

${ }^{42}$ Ibid., pp. 203-204. This consequence seems a clear indication of the prevalence of the state doctrine of massa mengambang/ lepas (floating mass) introduced in 1971. The doctrine was the ideological foundation of suppression of political activity of the people. According to this semi-official principle, people should be released from the restraints of political party activities which prevent them from devoting their full energy to economic development. This doctrine builds on the idea that people should cooperate in mutual assistance, consensus and Pancasila, rather than fight for their own political interests. See Hans Antlöv, Exemplary Centre, Administrative Periphery: Rural Leadership and the New Order in Java (Richmond: Curzon Press, 1995), pp. 36-7. The floating mass doctrine was not necessarily effective in de-politicizing the rural populace, not least because it did not target religious practices that often linked the supporters of non-government parties, especially the PPP, to their actual leaders, such as Friday mosque attendance and religious congregations (pengajian). See Ken Ward, "Soeharto's Javanese Pancasila," in Edward Aspinall and Greg Fealy (eds.), Soeharto's New Order and its Legacy (Canberra, ANU E Press, 2010), p. 27.

43 Musyawarah Nasional Alim Ulama NU (Munas Situbondo 1983 - the 1983 Situbondo Convention) and Muktamar ke-27 Situbondo 1984 (the 1984 27th Congress) indicated reconciliation between the NU and the Suharto's administration marking 
removal was somewhat less problematic to accept, in Madura, NU followers were undecided on whether to vote for the PPP in the next 1987 elections. The uncertainty was caused by many kiais who, unlike most kiais in Java, were still strongly affiliated with the PPP. A number of kiais in Madura believed that voting for Golkar would mean treachery to Islam. As a result the PPP remained the only feasible party to vote. To avoid confusion, the kiai decide to employ a more pragmatic attitude and persuade the nabdliyin to vote for a party that defends and promotes Islamic values. This was taken by the nabdliyin as a plea to vote for the PPP.

Muslim organisations, like the NU, were not explicitly democratic when they were founded. But, the NU was successful in gathering many followers, especially in rural areas. This was mainly due to the kiai networks and, as a result, the NU was successful in mustering kiai devotees into a more integrated group. In the New Order period in Madura, a more united group within the NU became the major force in rallying votes for the NU party and later for the PPP. This more integrated faction of the NU typically consisted of local religious leaders, such as kiai langgar, ustazin local madrasah, or imam/kiai of village mosques. After the NU decided to leave politics, these local religious leaders acted as political advisors for villagers' political concerns, perhaps because of their awareness of the world outside the village. The higher-ranking kiais or kiais from large pesantrens remained observant and applied a 'wait and see' strategy, although in the end most Madurese kiais kept their allegiance to the PPP. ${ }^{44}$ The PPP was still seen as a major channel of kiai socio-

the emergence of new elites in the NU board. The 1983 Convention resulted in two decisions: the departure of the NU from politics and the adoption of Pancasila as sole ideological base. The 27th Congress stressed this decision. See Michael R.J. Vatikiotis, Indonesian Politics under Subarto: Order, Development and Pressure for Change (London and New York: Routledge, 1993), p. 124; Francois Raillon, "The New Order and Islam, or Imbroglio of Faith and Politics," Indonesia, No. 57, 1993, pp. 197-217; Kees van Dijk, "Kiai and Politics," Bijdragen tot de Taal-, Land-en Volkenkunde, Vol. 152, No. 1, 1996, pp. 109-143; Martin van Bruinessen, NU, Tradisi, Relasi-relasi Kuasa, pp. 113-115. Prior to the 27th Congress, the chairman of the NU, Kiai Idham Chalid encouraged nabdliyin to have free political aspirations, being able to aligning themselves not only to the PPP, but also possibly to Golkar or the PDI (Jawa Pos, 31 August 1984).

${ }_{44}$ In other places, there were more kiais who were in favour of the departure of the NU from the PPP. For instance, prior to the 1983 Convention, and after the 1982 elections, several regional-national functionaries of the NU, such as Yusuf Hasyim, 
economic-political interests, and as an important network for reinforcing their ties with other kiais.

After the New Order collapsed, many Madurese kiai became more pragmatic in their political orientation. In the first two elections of 1999 and 2004, Partai Kebangkitan Bangsa (the PKB - the National Awakening Party), as the party backed by the NU leaders, enjoyed victory in all regencies in Madura. The PKB in return provided the NU with opportunities and financial support. Several members of the East Java local parliament from the PKB faction donated a small part of their salaries to the NU of East Java in the early 2000s. ${ }^{45}$ In the 2009 elections, although the party still won, the margin was insignificant. ${ }^{46}$ Apparently, the atmosphere in the Madurese political context has changed. As a comparison, during the New Order the NU's financial support derived primarily from contributions. Moreover, trading companies and businesses were established, and donations were collected to form stable financial resources for the organisation. ${ }^{47}$

Despite the accusation by some nabdliyin that the NU in Madura has been involved in politics too far, some segments of the NU in

supported the plan for the official withdrawal of the NU from the PPP. Hasyim became the most visible victim of PPP conflicts prior to the 1982 elections as he was moved from number 1 to number 32 on the list of the parliament candidates members from East Java province. See Martin van Bruinessen, NU, Tradisi, Relasi-relasi Kuasa, pp. 165-166. The position of general secretary of the PPP in its first National Congress/ Muktamar in 1984 was eagerly sought by many factions within the party. The NU was one of them. In a meeting at the NU headquarters at the same time as the muktamar, Kiai Hasyim Latief, the head of NU East Java, declared that if the NU did not occupy the general secretary position, the NU should withdraw itself from the PPP (Jawa Pos, 22 August 1984,). Mardinsyah, a non-NU politician, was elected as the general secretary of the PPP. He was assisted by six deputies, namely Yudo Paripurno, H.M. Ansyari Syam, Husni Thamrin, Ali Tamin, Djerkasy Noor, and Ismail Mokobombang (Jawa Pos, 23 August 1984).

${ }^{45}$ Interview with Kiai Nuruddin, a former member of Dewan Perwakilan Daerah (DPD - The Regional Representative Council) during the period from 2004 to 2009, representing the East Java province on 4 March 2011.

46 The number of seats in the DPRD Bangkalan achieved by political parties in the 2009 elections was as follows: PKB 10 seats, PPP 5, PKNN 5, Demokrat 4, PBR 3, PAN 3, Hanura 3, PDIP 2, PPD 2, PNBK 2, Republikan 2, Golkar 1, Gerindra 1, PDP 1, PKS 1 (Radar Madura, 22 April 2009).

47 Mansurnoor, Islam in an Indonesian World, pp. 123. 
Madura remain orthodox in terms of attitudes towards shari'a issues. A number of ulama in Madura, such as those of the Majelis Ulama Indonesia (MUI-the Council of Indonesian Ulama), the Muhammadiyah and the NU, have, responded negatively, to and publicly disapproved of, the discourse on Rancangan Undang-undang Hukum Terapan Pengadilan Agama Bidang Perkawinan (Legal Draft of Religious Court's Applied Law in Marriage Section), which penalises people who conduct an unofficial marriage (nikah siri), a marriage that is not recorded at the Local Office of Religious Affairs (Kantor Urusan Agama - KUA). Even though many Madurese ulama do not wish their daughters to become victims of nikah siri, they believe that nikah siri is lawful according to shari'a. ${ }^{48}$ It should also be noted that some kiais, predominantly those of lower rank in rural areas, still practice polygamy. Their second marriages are mostly nikah siri. It seems that disapproval of the Rancangan did not solely derive from a religious point of view. Furthermore, ulama in Bangkalan, such as those of the NU and Badan Silaturahmi Ulama Pesantren Madura (Bassra-the Association of Family of Madurese Pesantren Ulama) have mutually supported the proposal of Regional Regulation (Peraturan Daerah Perda) on the obligation for female government officers, and female students above nine years old, to wear jilbab (veil, headscarf), as proposed by the NU of Bangkalan. The proposal has been frequently quoted as compatible with the characteristic of Bangkalan as kota santri. Two young kiais, Imam Bukhori Kholil and Nasih Aschal, both descendants of Kiai Kholil, have underlined the obligation as a matter of urgency due to the number of female students and female employees in public spheres who do not completely cover their aurat/ awrat (the intimate parts of the body, for both men and women). ${ }^{49}$ The proposal has generated various reactions. Many support, and as some schools in Bangkalan openly do so, ${ }^{50}$ while only a minority of non-governmental organisations and academics object the obligation. ${ }^{51}$

In addition to matters of dress, the ulama of NU Sumenep have voiced concerns about love messages using mobile phones. The ulama believe that these 'vulgar' conversations are incompatible with shari'a.

48 www.nu.or.id, 23 February 2010, accessed on 6 September 2010.

49 www.nu.or.id, 31 July 2009, accessed on 7 September 2010.

${ }^{50}$ www.swarapendidikan.com, accessed on 22 August 2011.

51 http://cmars.synthasite.com/syahadah, accessed on 22 August 2011. 
They also believe that the individuals involved in phone conversation usually decide to meet and have illicit relationships. They also argue that many married couples have divorced because of these types of affairs. ${ }^{52}$ Nevertheless, these attitudes towards shari'a should not be seen solely as absolute indications of strict orthodoxy by all kiais of the NU in Madura, as many show no objection to traditional cultural elements such as karapan sapi (bull racing) that contradicts shari'a points of view.

The orthodox thoughts of the NU in Madura have been well preserved by the kiai as an ultimate symbol of santri Islam in Madura. This has ensured that the NU kiai are highly regarded among the nabdliyin. NU followers will participate in events organised by NU kiai if they know that many renowned kiai will also take part. Many of them blindly obey kiais words without further questioning the meaning behind the speech. Istighosah (communal prayer) is one of the most attended events organised by the NU, along with muktamar. Although other Muslim organisations also regularly hold the event, the NU usually attracts larger numbers. During the ethnic conflicts in Kalimantan, NU in Madura frequently conducted istighosah to pray for the safety of people who were severely affected by the conflict. One of the largest prayer meetings was held on 8 March 1997, fifteen East Javanese kiais led around 50,000 nabdliyin in prayer at the alun-alun (square) of Bangkalan..$^{53}$ Most nabdliyin were attracted by the presence of prominent kiais, such as Kiai Idris Marzuki of Lirboyo, Kiai Hasyim Muzadi, the head of the NU of East Java, and Kiai Abdullah Schal of Pesantren Demangan. Intresting, despite their participation in religious occasions, some nabdliyin are involved in kemaksiatan (sin, immoral acts). ${ }^{54}$ Regardless of this, the degree of obedience among NU followers in Madura to NU kiais and the NU itself is high so that the NU can be considered as 'religion' of the Madurese. There is a popular anecdote that illustrates the strong connection between the Madurese and the NU. It is said that the late Abdurrahman Wahid

52 www.kabarmadura.com, 19 December 2009, accessed on 13 September 2010.

53 Jawa Pos, 9 March 1997.

${ }^{54}$ Kiai Mashduki Fadly (a former parliament member as well as a leading kiai in Bangkalan) told me that he often noticed the madurese nabdliyin gambling and drinking alcohol. When approached, these individuals vowed never to repeat these actions, and proudly showed their NU identity card in their peci (prayer hat) (Interview with Kiai Mashduki Fadly on 1 December 2009). 
(Gus Dur, a former chairman of the NU and President of Indonesia) once visited Madura. A Madurese person proudly told Gus Dur that 99 per cent of Madurese people are Muslims, while only one per cent are Muhammadiyah followers. The story, despite its exaggeration, indicates that even today the rejection of Muhammadiyah -and also of reformed and modern Islam- by madurese is evident. It signifies a strong acknowledgement of the NU in Madura. The NU in Madura, is basiclly moderate and has been triumphant in establishing political moderation. ${ }^{55}$ It also indicates a high degree of accommodation and adaptation.

\section{The Emergence of Ulama as Religious Leaders}

A strict distinction between the term ulama and kiai does not appear in this paper. According to Deliar Noer, the term kiai indicates two kinds of people. The first comprises those whose knowledge of Islam surpasses that of ordinary man and who typically devote themselves to teaching of islam. The second type is closely related to a dukun (healer) who is associated with mystical and secret doctrines and practices all kinds of medicine. ${ }^{56}$ Hiroko Horikoshi distinguishes between the terms kiai and ulama. For Horikoshi, the difference lies primarily in the more extensive charisma that a kiai possess. The ulama play more roles in the social system and the social structure of villages and their ultimate status is legitimised by hereditary factors. Among the people, the kiai are higher than the village ulama, and their presence is regarded as a unifying symbol in society, since their moral and spiritual leadership is not tied to normative structure of a village. ${ }^{57}$ In Madura the term kiai has also a meaning in terms of leadership. In a broader context, the term ulama refers to men of Islamic learning and Islamic religious leaders in general. Hence, I use both terms, ulama and kiai, interchangeably.

Over centuries, religious leaders developed their own methods in disseminating Islam in Nusantara. During the late nineteenth and early twentieth centuries, haji played a pivotal role in the spread of Islamic

${ }^{55}$ Greg Barton, "The Prospects for Islam," in Grayson Lloyd and Shannon Smith (eds.), Indonesia Today: Challenges of History (Singapore: Institute of Southeast Asian Studies, 2001), p. 122; Mujani \& Liddle, "Indonesia’s Approaching Elections", p. 122.

${ }^{56}$ Deliar Noer, The Modernist Muslim Movement in Indonesia, 1900-1942 (Singapore: Oxford University Press, 1973).

57 Hiroko Horikoshi, Kiai dan Perubahan Sosial (Jakarta: P3M, 1987). 
thought in the Netherlands Indies. In that period, larger numbers of returning pilgrims added the number of religious leaders in the Indonesian archipelago. ${ }^{58}$ The number of people who performed the pilgrimage increased every year. In Madura in 1880 there were 896 haji, in 1885 there were 1,111, and five years later in 1890 there were 1,364. Haji who were not in charge of a pesantren were highly regarded, not because of their capability in religious knowledge, but mainly because of their financial ability to afford the expensive trip. In the second half of the nineteenth century, only a few farmers had the opportunity to perform pilgrimage, compared to better-educated people such as village secretaries. This changed in the early twentieth century as more farmers and merchants_-due to better economic conditions_-were able to go to Mecca. ${ }^{59}$

In the late nineteenth and early twentieth centuries, baji and kiai formed central elements of religious circles in Madura. It is not easy to separate haji and kiai in that period, exept that Kuntowijoyo believed that haji and kiai were different in many ways. According to him, kiai were not appropriate figures for organising modern social movements. Their charisma alone was not sufficient if it was not accompanied by the capability to arrange social movements. On the other hand, hajis were able to contribute to the ongoing social changes in society due to their high mobility and exploration of areas outside their places of origin. Even if a baji did not have adequate abilities in religious authority, his socioreligious status was highly appreciated. In distinguishing kiai and haji, Kuntowijoyo gives an example of a rebellious kiai in the village of Prajan in Sampang. This kiai acted not only as a religious teacher, but also as a dukun and a fortune teller. He delivered provocative sermons, requesting that villagers should take an active role in combating discrimination from the Dutch. The resulting uprising ended in the deaths of twenty villagers and injured twelve. ${ }^{60}$ Moreover, Kuntowijoyo argues that haji were more orthodox in identifying themselves with universal Islam. As an example of the haji group, he pointed to the hajis of Sarekat Islam,

${ }^{58}$ Sartono Kartodirdjo, The Peasants 'Revolt of Banten in 1888, Its Conditions, Course, and Sequel: A Case Study of Social Movements in Indonesia ('s-Gravenhage: Martinus Nijhoff, 1966), p. 155.

59 Kuntowijoyo, Perubahan Sosial, pp. 333-335.

${ }^{60}$ Ibid., pp. 337-45. 
who were belived to be pious individuals, as being merchants and urban citizens. Meanwhile, kiai belonged to the peasantry and village elites. In sum, he considered the kiai as power brokers with the ability to mobilise the people, whereas haji were cultural brokers. ${ }^{61}$ These suggestions seem to be inaccurate since it is not simple to draw a distinction between kiai and haji in the late nineteenth and twentieth centuries in Madura.

For example, although the well-known reformist Kiai Jauhari of Prenduan, Sumenep, was a teacher of Tijaniyah tarekat, he associated his pesantren with an Arab-oriented orthodoxy and sent his sons to modern Pesantren Gontor. One of his sons studied in Mecca and became a staff member of Muslim World League. To a large degree, Kiai Jauhari was considered more progressive than most other Madurese kiais, ${ }^{62}$ and played a pivotal role in Islamic resurgence. He adopted modern methods in his pesantren, which was rare in the Madurese pesantren circles at that time. Kiai Jauhari as both a kiai and a returned baji, along with other religious leaders in Prenduan, established a branch of the Hizbullah guerrillas. This guerrilla group, consisting of santri and pesantren graduates, was actively involved in the resistance against the Dutch during the Military Aggression of $1947 .{ }^{63}$ Under Kuntowijoyo`s classification, Kiai Jauhari acted as both a power broker and a cultural broker. Nowadays, all kiais from pesantren have to perform pilgrimage to Mecca in order to gain the respected title of 'Kiai Haji' (KH), which indicates the kiais reputation in both religious and economic realms.

Another example of kiai who acted as both a power broker and a cultural broker is the legendary Kiai Muhammad Kholil of Bangkalan, the most celebrated kiai in the history of Madura. There are many stories about this legendary figure, most of which are marked by myths. Kiai Kholil is probably one of the best examples of a returned baji who served as a religious teacher and a religious leader who spread his influence on society. He was born in the first half of the nineteenth century (between 1819 and 1835), and died around 1923-1925. ${ }^{64}$ He was known

${ }^{61}$ Kuntowijoyo, "Islam and Politics", pp. 108-38.

${ }^{62}$ Van Bruinessen, “Tarekat and Tarekat Teachers”, pp. 91-117.

${ }^{63}$ De Jonge, Madura dalam Empat Zaman, p. 256.

${ }^{64}$ No one knows the exact date of birth or death of this kiai, as his lifetime is not well documented. A recent book published in June 2010 gives a story from Kiai Muhammad Ghozi Wahib praising Kiai Kholil’s heroic role in the struggle against the 
not only as a wali (saint), but also as an expert in Arabic letters, a master in figh (Islamic jurisprudence), and mystical power. He is regarded as an important figure in the formation of a santri community in the Indonesian archipelago, where his renowned santri established new pesantren as soon as they returned to their places of origin. In other words, he produced kiai and laid down a strong foundation for the creation of a kiai-pesantren network. Today, a considerable number of Madurese and Javanese kiai consider him their indirect guru, because many leading kiais in Java, such as Kiai Wahab Hasbullah and Kiai Hasyim Asyari, two of the founders of the NU, studied in his pesantren ${ }^{65}$ Kiai Kholil is still alive in the minds of the Madurese, both those who live in the island and migrated some where else. To many pilgrims, his grave is considered as the final place in a pilgrimage for the people of Banten to Madura. When I visited Bangkalan in the last quarter of 2009, the mosque and the surrounding area of his grave was under construction. When I returned in the first quarter of 2011, the project was completed and several new facilities had been added.

For the present-day Madurese, religious leaders mean kiai. However, the term kiai in Madurese tradition is not static throughout time. In the earlier periods, kiai was a title for people who had a special characteristic, either in a positive or a negative sense. Therefore, a criminal or even a Chinese Muslim merchant could be called a kiai if he played a special role in society. Kiai was also a Madurese noble title. ${ }^{66}$ The Madurese noblemen, especially the regents, had close relationships with each other as they had family ties. In Pamekasan, for instance, a

\footnotetext{
'aggressors' on 10 November 1945 in Surabaya (p. 101). However, on an earlier page, the author writes that Kiai Kholil died in 1925 (p. 82). See Ibnu Assayuthi Arrifa i, Korelasi Syaikhona Muḅammad Kholil Bangkalan \& NU: Mengenang dan Menghayati Perjuangan Sang Inspirator (Kediri, Al-Haula Press, 2010). Many lower ranking ulama I have met often mentioned Kiai Kholil's epic participation in the struggle against the colonialists, both the Dutch and the Japanese, without being aware of the anachronism.

${ }^{65}$ Zamakhsyari Dhofier, Tradisi Pesantren: Studi tentang Pandangan Hidup Kiai (Jakarta: LP3ES, 1982); Martin van Bruinessen, "Tarekat and Tarekat Teachers"; Mokh. Syaiful Bakhri, Syaichona Kholil Bangkealan: Kiai Legendaris dari Madura (Pasuruan: Cipta Pustaka Utama, 2006); Saifur Rachman, Biografi dan Karomah Kiai Kholil Bangkalan: Surat kepada Anjing Hitam (Jakarta: Pustaka Ciganjur, 2001).

${ }_{66}$ Zainalfattah, Sedjarah Tjaranya Pemerintahan di Daerah-daerah di Kepulauan Madura dengan Hubungannya (Pamekasan: The Paragon Press, 1951), pp. 68-9.
} 
significant number of the descendants of Adikoro (one of the rulers of Pamekasan in the eighteenth century) became ulama in Pamekasan (Sumberanyar, Banyuanyar, Batuampar, and Tattango), Sampang (Prajan), and in some places in Java, such as Bondowoso (Blindungan, Pancagati, and Prajekan), Situbondo (Panjhi, Sukorejo, Asembagus, and Bajulmati) and Probolinggo (Klapasawit, Randupangger, and Kebonsari). Besides tracing their lineage back to Adikoro, these ulama were also said to be descendants of Sunan Giri and Sunan Bonang (two of the nine Javanese saints), and Pangeran Asmorokingking of Mataram. ${ }^{67}$

In contemporary Madura, there are several types of kiais. Kiai pesantren are generally regarded as the highest in rank. There are also kiai tarekat who usually lead a pesantren, But the letter are commonly known as tarekat teachers. The next category is kiai dukun, shamans or medicine men. The last and the lowest in the hierarchy of kiais in Madura is kiai langgar, who run a small mosque in villages. The first type of kiai is the real agents of socio-political-economic-cultural life in Madura, and is the most ideal representatives of the santriculture. They are what Eric Wolf identified as cultural brokers; people who 'connect the local system to the larger whole ${ }^{68}$ and who define what is appropriate for local society. Kiai pesantren and also kiai tarekat are cultural brokers due to their relative wealth. Kiai take advantage of their possessions, which may be in the form of materials, such as land or money, or non-material capital, such as the accumulation of knowledge.

In the nineteenth century, kiai tarekat, kiai pesantren and other religious figures, such as guru ngaji, imam (leaders of prayer), juru kunci (custodians of graveyards), merbot (gatekeepers of mosques), modin (muezzin), and naib (sub-district penghulu) were able to improve their positions within villages. This was particularly true for those were involved in arranging religious life in villages, including maintaining pesantren. They were needed especially during ritualistic festivities, which are still held preserved until the present day. ${ }^{69}$ Moreover, some kiais, besides showing

${ }^{67}$ Ibid., pp. 107-8.

${ }^{68}$ Eric R. Wolf, "Aspects of Group Relations in a Complex Society: Mexico," American Anthropologist, Vol. 58, No. 6, 1956, pp. 1065-78.

${ }_{69}$ The most famous are rokat desa and rokat bandaran. The former is an annual ritual to bless a village and to provide village inhabitants with harmony, safety and prosperity. The latter is a sea-based feast to sanctify the fishermen and ensure a great 
their capacities as men of Islamic learning, also performed mystical Islam rituals, such as fortune telling, healing people's illnesses and giving martial arts lessons. Supernatural powers, drawn from mystical Islam, were important attributes with regard to power and authority society. Madura, like other places in the Netherlands Indies in the nineteenth century, witnessed these situation.

Meanwhile, under pressure from the Dutch colonial administration, local elites slowly joined the administration during the nineteenth century. For religious figures and villagers, this meant that the elite had allied themselves with the infidel power. As a result, religious leaders and villagers were disappointed and dissatisfied, as they viewed the elite idealistically supposed tobe autonomous and influential leaders. The people then searched for others to provide guidance. Before the nineteenth century, native kingdoms had mufti, qadi, and law courts where, in many cases, shari a was implemented, usually in harmony with the foreign authorities' laws and customary regulations. ${ }^{70}$ This situation changed in the nineteenth century when they became mere tools of the colonial bureaucracy. After the East Indies were placed under the authority of Governor-General Herman Willem Daendels in 1808, he reorganised the administration. Daendels created a centralist government. All government affairs were under direct control of Batavia. The colonial government based the administrative mechanism on a western model, placing sultans and their families under the Dutch colonial government, and converting them into bureaucrats. Daendels's aim was to run the government under direct rule, so that he could rule the people without local leaders as intermediaries. ${ }^{71}$

However, people could not accept their leaders to be integrated into the colonial administration. Unlike local political elites, the religious figures such as kiai succeeded in preserving their independence. Villagers gradually turned to these religious figures. This does not mean that they only occupied a fundamental position among the villagers after Daendels

catch as well as safety. Despite the strong association with pre-Islamic beliefs, religious leaders are needed to lead these ceremonies. In turn, the religious leaders enjoy a highly respected position among the villagers as well as receiving economic benefits.

${ }^{70}$ Martin van Bruinessen, "Global and Local in Indonesian Islam" in Tonan Ajia Kenkyu, Vol. 37, No. 2, 1999, p. 164.

${ }^{71}$ Sartono Kartodirdjo, The Peasants`Revolt, p. 52. 
came into power. They had been central local leaders in religious, spiritual and limited social matters previously. The decline of the local elite's legal leadership led the ulama in turn to reinforce their position in society. The changes in the local hierarchy due to the Dutch colonial government in Madura can be seen as the main factor by which ulama tried to strengthen their position as religious leaders.

In the Indonesian archipelago during the nineteenth century when the implementation of colonial power became effective, religious leaders primarily emerged in the periphery and frequently rebelled against the local and Dutch authorities. ${ }^{72}$ In Madura, Islam in the nineteenth century reached a more systematic stage. Old pesantren grew fast and new ones were built. A number of well-off villagers became followers of kiai and facilitated them by financing their pesantren, a pattern that has continued until today. Hence, the emergence of kiai as religious leaders was, to some extent, a utilisation of local assets. ${ }^{73}$ Religious forum and discussion by the kiai pesantren, along with pengajian (Islamic congregations), gave kiai a sense of Islamic religious authority. Therefore, the patron-client relationship between kiai and their followers is predictable. ${ }^{74}$

\section{E. The Ties between Elements of the Santri Culture}

Madurese people have continuously preserved their own sacred values, as the three main elements of santri culture, pesantren, NU and kiai have had a great influence on society, in both religious and worldly domains. Moreover, these three main elements of santri culture form religious networks in Madura. The networks are controlled by the kiais who appear to have become a vital connector between the three elements above.

The oldest and most endurant tie that has been present for hundreds of years is perhaps the relationship between pesantren and kiai. Although kiai are able to exert their influence beyond the pesantren, but without a pesantren a Madurese kiai is like a captain without a ship. ${ }^{75}$ Highly motivated santri with financial aid from kiai parents and who have

\footnotetext{
${ }^{72}$ Martin van Bruinessen, "Global and Local", p. 164.

${ }^{73}$ Iik Mansurnoor, Islam in an Indonesian World, p. 36.

${ }^{74}$ Hiroko Horikoshi, Kiai dan Perubahan Sosial, p. 174.

${ }^{75}$ Interview with Kiai Mashduqie Fadly on 1 December 2009.
} 
finished their studies tend to build pesantren in their area of origin if they are able to do so. This often depends on support from the kiai of the pesantren where they studied, or marriage to a kiais daughter. The latter means that the future kiai will be supported by two families. These new kiais will be the mission of Madurese culture. If they study at various pesantrens, ties between new kiais and pesantren will be futher stegthened.

The second important tie is between pesantren and the NU. Unlike the Muhammadiyah, whose formal schools are spread all over the country, the NU has never built many formal schools. NU kiai believe pesantren, even in their most modern form, are still the most appropriate place to undertake religious learning and secular education. They also believe that establishing a pesantren will help maintain a kiais personal reputation as a guardian of Islamic values. Therefore, it is not surprising that until 1974, the number of religiously-based educational institutions (pondokpesantren and madrasab) in Madura was higher than the number of general schools. ${ }^{76}$ To large degree, NU kiai have encouraged the Nabdliyin to educate their children in pesantren, rather than in general schools. The NU followers, in turn, have enjoyed the services of kiai in the form of religious festivities and personal links.

Last but not least is the tie between the NU and kiai. The NU has provided the kiais with extensive networks which link kiai to the wider world. The organisation has also introduced kiai to the world of politics and social welfare. In turn, the NU has enjoyed a large number of villagers to the political party and later on to NU-associated political parties such as the PPP, the PKB or the PKNU. Kiais support has also been instrumental in financing the NU's regular events, such as the grand pengajian or tabligh akbar (grand tabligh, as a term tabligh means propagation of the messages of Islam). This perhaps indicates what Eric Wolf discusses in terms of group relations. He argues that the reliance of communities on a larger system affects them in two ways. Firstly, the whole communities play specialised roles within the larger context. Secondly, special functions pertaining to the whole become the tasks of special groups within communities in what Wolf calls 'nation-oriented groups. ${ }^{77}$ The NU kiai rely heavily on the NU as the larger system. Along

\footnotetext{
${ }^{76}$ Iik Mansurnoor, Islam in an Indonesian World, p. 170.

77 Eric R. Wolf, “Aspects of Group Relations”, p. 1065.
} 
with the Nabdliyin, the kiais preserve Islamic values as well as the sacred values of the Madurese. Within the NU, the special, political-economic, tasks are assigned to kiai who are more observant in worldly domains. These form the 'nation-oriented groups' who, according to Wolf, are 'frequently the agents of the great national institutions which reach down into the community'. ${ }^{78}$

\section{F. Conclusion}

In the present day Indonesia, religious life has not been integrated into the politics of the state, and although a number of religious leaders occupy bureaucratic positions, most religious elites in Indonesia are not affiliated with bureaucracy. However, they do continue to play important roles in Indonesia. In Madura, kiais are without doubt the main actors in state-society relations. They have become cultural, economic, and political brokers. By keeping their distance from the state, kiais have been successful in maintaining their positions in society. They have been aware of possible risk of being alienated and isolated not only from their followers, but also from their horizontal networks among religious circles. More importantly, they are concerned that their high position in society may gradually fade away if they do not keep their distance from the state. For some kiais, utilising their positions and personalities is a tool to gain and preserve positions and status. For others, focusing on religious matters is the decisive means by which they continuously adapt to changing situations, along with the rapidly changing administrations.

One may note that Islam has firmly established its position within local socio-cultural and socio-political configurations in Madura, and that Islam has been used and promoted by its supporters against secular state policies. However, it is impossible to answer the question 'Is Islam in Madura different from Islam in other places in Indonesia?' in one single formula. What we may witness is that unlike contemporary Aceh or Banten, which have been perceived as regions with a strong Islamic adherence and which seem to be increasingly shari'a oriented, Madura tends to cling strongly to Islamic values and norms without denying the presence of local syncretist cultures, and in fact the supporters of each culture shows that Islam and local traditions can live side by side.

\section{${ }^{78}$ Ibid.}




\section{BIBLIOGRAPHY}

Abdullah, Taufik, "The Pesantren in Historical Perspective," in Taufik Abdullah and Sharon Siddique (eds.), Islam and Society in Southeast Asia, Singapore: Institute of Southeast Asian Studies, 1988.

Antlöv, Hans, Exemplary Centre, Administrative Periphery: Rural Leadership and the New Order in Java, Richmond: Curzon Press, 1995.

Arrifa'i, Ibnu Assayuthi, Korelasi Syaikhona Muhammad Kholil Bangkalan \& NU: Mengenang dan Menghayati Perjuangan Sang Inspirator, Kediri, Al-Haula Press, 2010.

Azra, Azyumardi Azra and Dina Afrianty, "Pesantren and Madrasa: Modernization of Indonesian Muslim Society," Paper presented in Workshop on Madrasa, Modernity and Islamic Education, Boston University, CURA, May 6-7, 2005.

Bakhri, Mokh. Syaiful, Syaichona Kholil Bangkalan: Kiai Legendaris dari Madura, Pasuruan: Cipta Pustaka Utama, 2006.

Bappeda Kabupaten Bangkalan (BPS), Bangkalan dalam Angka 2000, Bangkalan: BPS Bangkalan, 2001.

----, Bangkalan dalam Angka 2000, Bangkalan: BPS Bangkalan, 2007.

Bappeda Kabupaten Sampang (BPS), Sampang dalam Angka 2000, Bangkalan: BPS Sampang, 2001.

----, Sampang dalam Angka 2010, Bangkalan: BPS Sampang, 2011

Barton, Greg, "The Prospects for Islam," in Grayson Lloyd and Shannon Smith (eds.), Indonesia Today: Challenges of History, Singapore: Institute of Southeast Asian Studies, 2001.

Boland, Bernard Johan, The Struggle of Islam in Modern Indonesia, The Hague: Nijhoff, 1982.

Brakel-Papenhuyzen, Clara, "Javanese Taledhek and Chinese Tayuban," Bijdragen tot de Taal-, Land- en Volkenkunde, Vol. 151, No. 4, 1995.

Bruinessen, Martin van, NU, Tradisi, Relasi-relasi Kuasa, Yogyakarta: LKiS, 1994.

----, "Pesantren and Kitab Kuning: Continuity and Change in a Tradition of Religious Learning," in Wolfgang Marschall, Texts from the Islands: Oral and Written Traditions of Indonesia and the Malay World, Bern: 
Institute of Ethnology, University of Bern, 1994.

----, "Shari'a Court, Tarekat and Pesantren: Religious Institutions in the Banten Sultanate," Archipel, Vol. 50: Banten Histore d une Region, 1995.

----, "Tarekat and Tarekat Teachers in Madurese Society," in Kees van Dijk, Huub de Jonge and Elly Touwen-Bouwsma (eds.), Across Madura Strait: the Dynamics of an Insular Society, Leiden: KITLV Press, 1995.

----, "Global and Local in Indonesian Islam", Tonan Ajia Kenkyu, Vol. 37, No. 2, 1999.

----, "Traditionalist and Islamist Pesantrens in Contemporary Indonesia," in Farish A. Noor, Yoginder Sikand and Martin van Bruinessen (eds.), The Madrasa in Asia: Political Activism and Transnational Linkages, Amsterdam: Amsterdam University Press, 2008.

Burhanudin, Jajat, "Islamic Knowledge, Authority and Political Power: the Ulama in Colonial Indonesia," Ph.D. dissertation, Leiden: Leiden University, 2007.

Colbran, Nicola, "Realities and Challenges in Realising Freedom of Religion or Belief in Indonesia," The International Journal of Human Rights, Vol. 14, No. 5, 2010.

Dhofier, Zamakhsyari, Tradisi Pesantren: Studi tentang Pandangan Hidup Kiai Jakarta: LP3ES, 1982.

Dijk, Kees van, "Kiai and Politics," Bijdragen tot de Taal-, Land-en Volkenkunde, Vol. 152, No. 1, 1996.

Feillard, Andrée, NU vis-à-vis Negara: Pencarian Isi, Bentuk dan Makna, Yogyakarta: LKiS, 1999.

Hefner, Robert W., "Islamizing Java? Religion and Politics in Rural East Java," The Journal of Asian Studies, Vol. 46, No. 3, 1987.

Hisyam, Muhammad, "Potret Penghulu dalam Naskah: Sebuah Pengalaman Penelitian," Wacana, Vol. 7, No. 2, 2005.

Horikoshi, Hiroko, Kiai dan Perubahan Sosial, Jakarta: P3M, 1987.

Hughes-Freeland, Felicia, "Tayuban: Culture on the Edge," Indonesia Circle, No. 52, 1990. 
Jonge, Huub de, Madura dalam Empat Zaman: Pedagang, Perkembangan Ekonomi, dan Islam: Suatu Studi Antropologi Ekonomi, Jakarta: Gramedia, 1989.

Kartodirdjo, Sartono, The Peasants 'Revolt of Banten in 1888, Its Conditions, Course, and Sequel: A Case Study of Social Movements in Indonesia, `s-Gravenhage: Martinus Nijhoff, 1966.

Kuntowijoyo, "Islam and Politics: the Local Sarekat Islam Movements in Madura, 1913-20," in Taufik Abdullah and Sharon Siddique (eds.), Islam and Society in Southeast Asia, Singapore: Institute of Southeast Asian Studies, 1988.

----, "Agama Islam dan Politik: Gerakan-gerakan Sarekat Islam Lokal di Madura, 1913-1920," in Huub de Jonge, Agama, Kebudayaan, dan Ekonomi: Studi-studi Interdisipliner tentang Masyarakat Madura, Jakarta: Rajawali Pers, 1989.

----, Perubahan Sosial dalam Masyarakat Agraris Madura, 1850-1940, Yogyakarta: Matabangsa, 2002.

Lukens-Bull, Ronald "Teaching Morality: Javanese Islamic Education in a Globalizing Era," Journal of Arabic and Islamic Studies, Vol. 3, 2000. Mansurnoor, Iik, Islam in an Indonesian World: Ulama of Madura, Yogyakarta: Gadjah Mada University Press, 1990.

Morris, Eric Eugene, Islam and Politics in Aceh: a study of Center-Periphery Relations in Indonesia, Ithaca: Cornell University Press, 1983.

Mujani, Saiful and R. William Liddle, “Indonesia’s Approaching Elections: Politics, Islam, and Public Opinion," Journal of Democracy, Vol. 15, No. 1, 2004.

Nakamura, Mitsuo, The Crescent Arises over the Banyan Tree: a Study of the Mubammadiyah Movement in a Central Javanese Town, Yogyakarta: Gadjah Mada University Press, 1983.

Noer, Deliar, The Modernist Muslim Movement in Indonesia, 1900-1942, Singapore: Oxford University Press, 1973.

Pemberton, John, On the Subject of "Java", Ithaca: Cornell University Press, 1994.

Rachman, Saifur, Biografi dan Karomah Kiai Kholil Bangkalan: Surat kepada Anjing Hitam, Jakarta: Pustaka Ciganjur, 2001. 
Raillon, Francois, "The New Order and Islam, or Imbroglio of Faith and Politics," Indonesia, No. 57, 1993.

Ricklefs, Merle Calvin, Polarising Javanese Society: Islamic and Other Visions, c. 1830-1930, Leiden: KITLV Press, 2007.

Saby, Yusny, "Islam and Social Change: the Role of the Ulama in Acehnese Society," Ph.D. dissertation, Temple University, 1995.

Samson, Allan A., "Conceptions of Politics, Power, and Ideology in Contemporary Indonesian Islam," in Karl D. Jackson and Lucian W. Pye (eds.), Political Power and Communications in Indonesia, Berkeley: University of California Press, 1978.

Saputro, Muhammad Endy, Kiai Langgar and Kalebun: A Study on Contestation between Cultural Brokers in a non-Pesantren Village in Madura, Indonesia, Yogyakarta, Graduate School Gadjah Mada University, 2009.

Touwen-Bouwsma, Elly, "The Ulama of Madura: Rise and Expansion of a Religious Regime," in Mart Bax, Peter Kloos and Adrianus Koster (eds.), Faith and Polity on Religion and Politics, Amsterdam: VU University Press, 1992.

Vatikiotis, Michael R.J., Indonesian Politics under Suharto: Order, Development and Pressure for Change, London and New York: Routledge, 1993.

Ward, Ken, "Soeharto's Javanese Pancasila," in Edward Aspinall and Greg Fealy (eds.), Soebarto's New Order and its Legacy, Canberra, ANU E Press, 2010.

Wolf, Eric R., "Aspects of Group Relations in a Complex Society: Mexico," American Anthropologist, Vol. 58, No. 6, 1956.

Zainalfattah, Sedjarah Tjaranya Pemerintahan di Daerah-daerah di Kepulauan Madura dengan Hubungannya, Pamekasan: The Paragon Press, 1951. 